\title{
Geotechnical design verification and performance assessment of tailings storage facilities
}

\author{
M. Shelbourn Barrick Gold of North America Inc., United States of America
}

\begin{abstract}
Tailings storage facilities can represent one of the greatest risk sources for a mine site, and the geotechnical design of any such facility should be conducted at a level appropriate for the satisfactory management of that risk. During operation, work is required to verify the geotechnical design parameters and conditions, which, at least for the deposited tailings, must often be assumed in the design stage, and to assess the performance of the facility, including consideration of eventual closure and reclamation.
\end{abstract}

Topographic surveys, piezocone soundings, piezometer readings and seepage monitoring are among the most commonly used methods to characterise storage capacity, strength, rate of consolidation, porewater pressure and seepage conditions within tailings deposits. Some aspects of the collection, presentation and use of data from these monitoring and in situ testing methodologies for verifying geotechnical design assumptions are discussed in this document, with particular reference to tailings facilities for which structural support is provided by the impounded tailings. Advances in equipment, field work and data acquisition have improved the quality and quantity of geotechnical information and should lead to further development of tailings-specific geotechnical databases and correlations at each mine site and across the industry as a whole.

\section{Introduction}

While the increasingly stringent demands of fiscal performance, environmental stewardship and social accountability are likely to drive future mineral processing to the generation of drier waste products, most mine tailings are still discharged as conventional slurry of mineral solids and process fluids into aboveground storage facilities. These tailings streams are characterised by moderate solids contents, relatively low fluid yield strengths and the corresponding ability to be segregated into coarse tailings (sands), fine tailings (slimes) and free water (the decant pond) in the tailings deposits through subaerial beach discharge, hydrocycloning or other sorting methods. Tailings storage facilities often represent the greatest single risk source for many mining projects during operation and well into the post-closure period.

Although numerous published references for tailings parameters are available (e.g. Vick, 1990; Qiu and Sego, 2001; Bussière, 2007), project-specific geotechnical characterisation usually cannot be completed until well into the active mine life, during which considerable variations can occur due to changes in the ore body, mineral processing and the processes associated with tailings deposition, consolidation and impoundment operation. In contrast, the geotechnical properties of native borrow materials and geosynthetic products can often be tested extensively during tailings storage facility design and initial construction, and are not usually expected to vary significantly over the operating and immediate post-closure life.

The complex spatial and temporal variation within slurried tailings deposits are thus well-recognised, but (pragmatically) simplified for initial design with corresponding limitations acknowledged on predicted geotechnical behaviour. Responsible tailings stewardship and risk management thus invoke the obligation to confirm design parameters and assess performance through appropriate monitoring and testing during operation. Verification of tailings geotechnical and hydrogeological behaviour is particularly critical for those facilities in which the impounded (and consolidating) tailings govern physical stability, of which the upstream-raised impoundments in Western Australia - a mining region well-suited for such construction, in terms of arid, relatively low-seismic conditions - are an example. The structural stability of thickened and paste tailings storage facilities (also assuming competent underlying foundation conditions) is likewise governed by the impounded tailings, a key consideration when perimeter embankments are progressively raised to confine deposits within pre-established footprints in order to increase stack heights. On perhaps a 
more basic level, monitoring of realised versus predicted impoundment volumetrics is required to validate tailings storage capacity design and develop closure planning while seepage monitoring assists with tracking consolidation progress and demonstrating compliance to environmental standards.

\section{$2 \quad$ Monitoring and in situ testing - four fundamental methodologies}

The completion of topographic surveys, piezocone soundings, piezometer readings and seepage monitoring in tailings deposits constitute the most common, economic, useful and generally accessible methods of assessing facility performance and verifying geotechnical parameters, which may in turn lead to the adoption of revised values or changes to facility operations. This work should be undertaken at regular and appropriate intervals during operation and supported by other monitoring and in situ testing procedures, geotechnical laboratory testing of tailings samples and (as required) geochemical tailings and water analyses.

An understanding of the geotechnical properties and condition of the tailings deposit itself is fundamental to the stewardship of any facility for which any significant amount of structural support is provided by the impounded tailings. The importance of topographic survey, piezocone sounding, piezometer reading and seepage monitoring information to the stewardship of such tailings storage facilities is widely recognised, and the respective field programs are conducted to varying degrees at most well-managed operations. This document reviews some considerations related to the collection, presentation and use of data from these four basic monitoring and in situ testing methodologies, and notes the benefits to individual operations and the mining industry as a whole in developing tailings-specific geotechnical databases and empirical correlations.

\subsection{Topographic surveys}

Regular topographic surveys of the tailings surface are fundamental to verifying that the impoundment is being filled in an efficient manner, consistent with the deposition plan and estimated settlement and consolidation behaviour, and that elevation and distance-related performance indicators are being tracked. Careful topographic survey work is also integral to deformation monitoring of embankment slopes and downstream toe areas, often by precise location of reflective targets embedded to a nominal depth in the embankment slope. For the purposes of this document, however, discussion is restricted to measurements of the impounded tailings surface in the subaerial zone (beach above water) and the decant pond (beach below water), usually in relation to the impounding embankment crest or native ground upstream.

At present, routine measurement of the impounded tailings surface is most commonly conducted using global positioning system (GPS) equipment or by airborne photogrammetry with ground control targets. Bathymetric surveys are typically carried out using conventional, weighted-line sounding methods and/or with echo-sounding equipment in cases where maintaining a steady position over a long weighted line (i.e. deep pond locations) is problematic due to boat movement or the submerged tailings surface cannot easily be sensed. Results from regularly scheduled topographic surveys provide valuable assessment of the validity of the geotechnical parameters (and associated water management conditions) estimated for the original design, particularly when reviewed alongside well-documented operational data such as tailings discharge densities and locations. Some considerations and examples are outlined below.

Documentation of pre-deposition conditions: The reference topography for a tailings deposit is the precommissioning ground surface, including mapping of subsurface soil and bedrock conditions, identification of natural seepages and delineation of any impoundment excavations during construction. Details of any installed consolidation water collection systems must obviously also be recorded. Future performance issues such as unusually large seepage flows may be correlated, for example, to a paleochannel or borrow operations within the impoundment that were not considered significant in the facility design. The planning and execution of in situ testing, sampling and borehole instrumentation programs during operation and postclosure depend on reliable knowledge of basin floor conditions, particularly for work in lined facilities. As well, accurate tailings consolidation modelling in particular and effective closure planning, to a great extent, cannot proceed without an adequate understanding of pre-deposition basin geometry, ground conditions and seepage collection systems. Although an accurate topographic survey and record of pre-deposition basin conditions should be a standard component of the as-built starter facility documentation, critical details such as final borrow areas and depths or seepage collection pipe header locations are too often recorded only in field notes or left to memory of those involved in the construction. 
Beach angle and profile verification: The empirical relationships between hydraulically-deposited tailings properties, most notably pulp density and particle size distribution, and sub-aerial beach angles have been well documented (e.g. Vick, 1990; Blight, 2003), and more sophisticated computational tools are becoming available to guide prediction of tailings surface development. Increased attention to beach angle modelling and design verification via topographic survey is being driven by the significant effect the realised profile has on storage volume, surface configuration and ultimate footprint as tailings generation rates increase with developments in mineral processing technology and the commissioning of larger mining projects, often of lower ore grade (Eldridge et al., 2007; Fourie, 2006). Tailings beach angle and profile prediction, as well as quantification of discharge flow path development for thickened and paste tailings (Engels et al., 2006) would benefit from the systematic collection of tailings surface elevation, discharge operation and material characterisation data within designated monitoring section(s), allowing calibration of discharge and deposition models and better understanding of scale effects associated with small-scale sedimentation and flume testing.

Rate of rise confirmation: Design rate of rise criteria are of particular concern for pore water pressure generation and geotechnical stability of upstream-raised tailings impoundments. Regular topographic survey work is essential for demonstrating adherence to design rate of rise values, which are often regulatory requirements, and for detecting trends away from the design values that may result in significant deviation from the timing of crest raising campaigns (particularly critical to multiple-cell operations with scheduled deposition and fallow periods) and achieving ultimate configurations. Final design heights are usually stated in regulatory approvals for tailings impoundments, and receiving approval to increase heights to accommodate originally intended tailings quantities or to provide interim time to develop replacement facilities is often difficult.

Freeboard requirement compliance: Commensurate to rate of rise verification, timely survey programs are essential for ensuring conformance with freeboard requirements. Encroachment of minimum freeboard criteria should not ordinarily be of concern for correctly designed and operated upstream-raised facilities which require a small decant pond kept far away from embankment slopes to ensure an adequate extent of drained, sand tailings beach above water. Verification of freeboard allowance and stormwater management capability is perhaps more critical to thickened and paste tailings deposits, which typically have irregular, superelevated (with respect to the perimeter embankments) surfaces that can concentrate runoff water over relatively small areas, usually adjacent to the embankments.

Achievement of key performance indicators: Design ranges for the decant pond size (area and volume), location and associated width of the tailings beach above water are declared key performance indicators at many tailings storage facilities. Regular collection and review of topographic survey data allows direct measurement and verification of trends to or away from the design ranges. As required, the survey results also provide unambiguous support for enacting change to tailings management (e.g. better thickening or increased decant reclaim) and/or discharge (e.g. improved spigot distribution and cycling) processes to achieve these key performance indicators and thus ensure compliance with underlying design operating conditions.

Water and materials balance model calibration: Survey-verified beach above water and decant pond areas are an essential component for the calibration of water and materials balance models, and frequent survey work coupled with photographic documentation can help quantify the relative timing of wet (active) discharge and dry (inactive) desiccation beach areas. For more complex or process-critical water balance situations, additional effort may be required to delineate the relative water contents and associated evaporation rates from wet and dry beach areas (Blight, 2001; McPhail, 2005). At smaller impoundments with well-controlled decant ponds, an adequate estimate of the pond volume and tailings beach below water surface for design verification purposes may be achievable by measuring the depth to the fine tailings surface around the decant tower and assuming a typical (empirical-based) underwater slope back to the pond perimeter. This approach, conducted (for example) bimonthly and calibrated by annual (for example) detailed bathymetric surveys, may greatly improve the functionality and predictive capability of water balance models over those based on annual detailed bathymetric surveys alone.

Correlation to monitoring and in situ testing data: Comparisons to past and planned future in situ testing (e.g. piezocone) data and possible correlation to pore water pressure monitoring results require verification 
of tailings and decant pond surface elevations. In particular, adjacent tailings and pond elevations should be systematically recorded at least as frequently as the instrument is read so that pore water pressure responses to loading can be reviewed with confidence, rather than approximated on the basis of (for example) annual topographic survey campaigns.

Identification of unusual conditions: Regular collection and examination of tailings surface survey data may help identify progressive changes not easily recognisable or quantifiable by visual monitoring alone, but potentially indicative of gradually deteriorating geotechnical conditions. As an example, a persistent, wide and subtle beach-area depression not related to variations in tailings supply volumes could indicate an internal filter problem in the case of a rockfill shell embankment design.

Tracking of consolidation progress and assessment for enhanced consolidation: The results of periodic topographic surveys, reviewed with pore water pressure data and other information, support estimates of realised and predicted future tailings consolidation rates and completion of cost/benefit analyses of wick drain installations or other methods to accelerate consolidation. Given the importance of consolidation monitoring and prediction in estimating storage costs and schedules for most tailings facilities, the completion of regular, sufficiently detailed and accurate impoundment surface surveys to validate currently available consolidation models should be considered standard operating practice. As well, the continued development of fully-coupled, three-dimensional, large-strain consolidation software, which has only recently become feasible due to the availability of relatively inexpensive computational speed (M.D. Fredlund, 2009, written comm.), will rely in great part on calibration with detailed topographic survey data.

Pre-closure discharge strategy development: Regular review of surface topography becomes critical to closure planning towards the end of the design operating life, as tailings deposition usually needs to be adjusted to infill low points and achieve design final configuration, with allowance for predicted consolidation. Subject to filling, evaporation and consolidation rates, arid-region mine operations with multiple-cell tailings facilities may be able to incorporate topping-up to increase storage efficiencies (Seneviratne et al., 1996) within the overall life of mine plan, and the potential for and timing of the additional, final tailings deposition can be verified through review of survey data.

Like most other technical aspects of tailings characterisation and monitoring, considerable advances have been made in topographic survey practice. Land-based equipment using GPS technology is readily available at modest cost, airborne methodologies (photogrammetric and laser-based) claim resolution to centimetre accuracy, satellite information can be used in conjunction with land record data and geographic information system (GIS) technology is being expanded to integrate remote sensing data and provide rapid and accurate spatial data management, correlations and analyses (Morgenstern and Martin, 2008) that in time will surely assist in tailings facility stewardship. Bathymetric surveys of decant ponds can be carried out under real-time GPS positioning and employing sophisticated echo-sounding equipment, with readily-available software to generate accurate water depth and tailings surface contours. Engels et al. (2006) note the relative advantages of remote sensing techniques and conventional on-site survey methodology in collecting elevation data, including the use of specialised vehicles to access soft tailings and decant ponds.

Regardless of the methodology employed, responsible stewardship demands regular completion of topographic survey work and adequate review of tailings surface elevation data. Pertinent tailings deposition history should be recorded on corresponding (chronologically appropriate) survey plans to indicate any areas of geotechnical interest. An example, the low point of the pre-deposition basin floor adjacent to an embankment may contain significant thicknesses of weak or saturated materials due to initial discharge and pooling of slimes and free water, prior to perimetral beach development. Reference to available photographic (land and aerial) archives is usually of great value to the chronological review of tailings surface development, and contemporaneous contour overlays should be produced for vertical air photos, if not automatically generated by the airborne photogrammetric work. The additional effort of reviewing deposition history and surface development will usually be of great assistance to the planning and execution of in situ testing and monitoring programs as well as the interpretation of observed seepage behaviour.

\subsection{Piezocone soundings}

The development of in situ penetration testing technology and the application and interpretation of data from piezocone soundings have been extensively documented in the literature (e.g. Lunne et al., 1997; Schnaid, 
2009) and at international workshops and conferences. As indicated by Davies et al. (2002), the piezocone provides a rapid and reliable method of measuring soil response to continuous penetration and porewater pressures (through dissipation testing), from which soil type, shear strength, state, sensitivity, relative density/consistency, liquefaction susceptibility, hydraulic conductivity and consolidation parameters can be estimated. Seismic piezocones also allow the collection of shear wave velocity data at regular intervals, as well as refined estimates of shear and Young's moduli, soil density and void ratio parameters. Robertson (2009) provides a review of piezocone test-based relationships for evaluating flow liquefaction potential and estimating liquefied shear strength, including reference to several tailings deposits. Advances in penetration testing (from work carried out in natural sediments) of interest to the geotechnical characterisation of tailings deposits include the use of full-flow penetrometers instead of piezocones to reduce the influence of overburden pressure on shear strength measurements (Stewart and Randolph, 1994; Weemees et al., 2006) and consideration of the influence of partial consolidation on piezocone response with respect to normalised penetrometer velocity (Schneider et al., 2008). Perhaps the most significant advances for geotechnical piezocone work will be the further development of the cone pressure meter to help infer in situ horizontal stress conditions and thus reduce uncertainty in the estimate of soil state and other parameters, and methods to overcome desaturation of the porewater pressure sensor when the piezocone is pushed through dilatant, fine-grained soils. Schnaid (2009) provides a brief summary of new developments in piezocone technology.

The structural stability of upstream-raised impoundments for which engineered embankment walls are constructed (commonly by placing and compacting lifts of borrow material, usually sand tailings from the adjacent beaches) is governed by the strength of the underlying deposited tailings rather than the relatively thin embankment walls themselves. Piezocone soundings provide a relatively rapid, inexpensive and reliable way to characterise these deep tailings foundation conditions, and through empirical correlations supported by theoretical soil mechanics concepts and any available, site-specific laboratory testing data, verify geotechnical design parameters. Sounding locations are typically arranged to provide subsurface information relevant to the slope stability analysis sections developed for the original tailings impoundment design, including the critical section(s) which normally comprise the maximum facility height, foundation conditions of concern and/or high failure consequence orientations (i.e. critical structures located near the downstream toe). However, additional piezocone soundings may be warranted to investigate abnormal operating or monitoring conditions, such as zones where impoundment-filling records indicate extensive quantities of slimes accumulated adjacent to an embankment wall or where piezometric data indicate porewater pressures in excess of design estimates. The location of piezometers and other borehole instrumentation - existing and contemplated - should also be considered in planning piezocone work.

As previously noted, topographic survey data should be obtained for the completed piezocone sites, and the decant pond water surface proximity and elevation recorded, to facilitate comparison with existing and future piezocone and piezometer data. Accurate, as-completed position and elevation data are too often omitted, possibly due to uncertain program completion timing, the absence of permanent installations at piezocone sites and the perception that the recorded depths and general knowledge of the existing embankment and impounded tailings surface are adequate for interpreting and applying the piezocone data to the review analyses at hand. However, the excellent reliability and repeatability of the piezocone should be leveraged in characterising in situ conditions over time, for which accurate survey locations are of considerable assistance.

Undrained shear strength and soil state are two examples of geotechnical parameters governing the design and performance assessment of upstream-raised tailings impoundments that can be examined through the interpretation of piezocone data. Undrained shear strength, as obtained from the most-widely used empirical correlation (Schnaid, 2009) for cohesive soils, is related to the difference between piezocone tip resistance (corrected for porewater pressure acting on the tip during penetration) and estimated total in situ vertical stress via an empirical cone factor. A perhaps less-commonly used correlation uses a different cone factor to relate the difference between dynamic and equilibrium porewater pressures to undrained shear strength. Both methods apply to undrained shear in saturated soft clay, which may not represent well the silty sand to clayey silt conditions typical of many tailings deposits.

The state parameter provides an indication of soil behaviour (contractant or dilatant) and liquefaction potential under applied shear, and thus is a useful performance assessment metric for upstream-raised tailings impoundments. Jefferies and Been (2006) discuss the evaluation of liquefaction potential and state parameter 
from piezocone data, and numerous published documents provide reviews and technical analyses of liquefaction failures in tailings facilities and assessments of liquefaction potential specific to hydraulicallydeposited tailings. At a screening level, state parameter can be estimated via relationships with normalised piezocone measurements following the methodology of Plewes et al. (1992) which incorporates tip resistance, friction ratio and porewater pressure or that of Robertson (2009) which incorporates tip resistance and friction ratio only. The ratio of small strain shear modulus to tip resistance, both normalised to existing effective stress and obtained through use of a seismic piezocone, can also be related to in situ soil state and thus to state parameter if details of the critical state line are known (Lunne et al., 1997). At a detailed evaluation level, complementary laboratory and other in situ testing methods are used to determine the critical state soil parameters and existing stress conditions needed to invert (recover) the state parameter from the measured piezocone tip resistance, normalised to the mean effective stress (Jefferies and Been, 2006; Shuttle and Cunning, 2007).

A common factor in the verification of these two examples of geotechnical parameters, undrained shear strength and soil state, from piezocone sounding data is the incorporation of dynamic (penetration) and/or static (equilibrium) porewater pressures. Equilibrium porewater pressure is the only condition or property of a tailings deposit that can be measured directly (and reasonably efficiently, considering data quantity, reliability and cost) by the piezocone (through dissipation testing), as well of course from piezometer installations. Tip resistance, sleeve friction and penetration porewater pressures are measures of the soil response to penetration.

Given the importance of equilibrium porewater pressure values to the derivation of geotechnical strength and state parameters and the requirement for dissipation testing to estimate permeability and consolidation characteristics, dissipation testing should be conducted at relatively closely-spaced intervals throughout the piezocone profile within inferred saturated zones, at least for key sounding locations and depths and with consideration of overall tailings deposit depth, available piezometer data and specific dissipation time requirements. Relatively frequent dissipation testing in saturated, positive porewater pressure conditions should also help drive any small air bubbles in the porewater pressure sensor back into solution, thus improving dynamic pressure response readings in immediately following penetration intervals (Robertson, 2009). The potential to help ensure pressure sensor saturation through regular dissipation testing is likely of great benefit for most tailings deposit piezocone work, where porewater pressure, saturation and soil behaviour conditions can vary greatly over small depths.

Dissipation testing data also assist in the understanding of seepage gradient conditions within the tailings deposit, particularly in the absence of extensive piezometer coverage, which is essential, for example, to verify the design performance of underdrain seepage collection systems, characterise and predict consolidation and evaluate enhanced consolidation works such as wick drains. Martin (1999) and le Roux (2002) emphasise the importance of piezocone dissipation testing to validating piezometer-based porewater pressure characterisation in tailings deposits; equally, available piezometer data should be used to verify that nearby dissipation testing results and inferred seepage gradients appear reasonable.

\subsection{Piezometer readings}

The verification of design assumptions related to the geotechnical performance of tailings facilities for which the impounded tailings govern structural stability relies on an understanding of soil state and strength conditions, best investigated via periodic piezocone work, and an associated understanding of pore water pressure conditions, best monitored over time via appropriately designed piezometer installations and timely collection and review of piezometric data. A significant and now well-established advance in pore pressure monitoring within tailings deposits has been the use of vibrating wire piezometers, which only require nearzero volume displacements to detect changes in the pore water pressure regime, particularly when completed as push-in or grouted in-place borehole installations that avoid the construction of filter sand zones around the transducer tip and when read using automated data acquisition systems. Vibrating wire piezometers usually have integrated thermistors to correct pressure data for temperature fluctuations, though the effect is rarely significant for geotechnical stability applications. As noted further below, however, these temperature data should be collected and reviewed. Vibrating wire piezometers can readily be configured in nested (vertically spaced) configurations in borehole installations, thus allowing evaluation of seepage gradients and pore water pressure distribution within the tailings deposit to detail adequate for geotechnical design 
verification. Potential limitations specific to tailings deposit use include corrosion in chemically aggressive environments or crust (crystal) growth in highly saline environments that could block the filter, particularly if subject to drying and wetting associated with tailings deposition cycling.

Standpipe piezometers offer the possibility of conducting slug or injection tests to estimate hydrogeological parameters and extracting water samples for geochemical testing. The need to characterise hydrogeological properties or water quality at any time from tailings impoundment monitoring locations should be considered in the selection of piezometer type. However, the construction of bentonite seal and filter sand zones at depth as normally required to build standpipe piezometers at depth is time-consuming, sometimes suspect in isolating the screened interval from vertical migration of water and rarely practicable for nested installations. Standpipe piezometers intended for dual purpose as geotechnical monitoring and water sampling devices necessarily require screened intervals of limited length to provide reasonable estimate of (and response to) porewater pressure conditions for the former use, thus potentially hindering their efficiency for the latter. A more effective approach, should the need for water sampling within impounded tailings arise, would be the construction of an observation well (i.e. a standpipe installation screened over a significant length in the zone of interest) and an accompanying (but located sufficiently far away to avoid interference) nested vibrating wire piezometer installation, or limited screened interval standpipe installation if permeability testing is the objective. Shallow standpipe installations however can help investigate apparent seepage zones along the downstream slope of tailings embankments or verifying foundation conditions for upstream raise construction. They can be installed inexpensively and rapidly via test pits or fence post auger holes and backfilled with the spoil material to approximate pre-existing conditions. As temporary, shallow subsurface water monitoring points that are easily replaced as required, construction of bentonite seals and filter sand zones are not usually warranted - geotextile cloth wrapped around the perforated pipe sections will suffice.

Vick (1990), Martin (1999) and le Roux (2002) discuss the importance, variation, monitoring and application of porewater pressure conditions for the assessment of geotechnical stability of tailings impoundments, with guidance specific to the appropriate use of transducer-based and standpipe piezometers. Appropriately designed and monitored piezometer installations can also provide valuable information for the evaluation of seepage flux and consolidation rates and the related efficacy of seepage underdrainage systems, transient response to rapid loading or temporary flooding at the impoundment surface, and effective layout and timing of piezocone sounding programs, for example. Perhaps still too many piezometer monitoring programs are focused on data acquisition (often employing a limited number of standpipes read at the lowest recommended rate) strictly for comparison to trigger and action response plan 'depth to water surface' values as defined by the results of slope stability analyses that, for want of adequate piezometer coverage and piezocone dissipation testing, assume incorrect porewater pressure conditions (often hydrostatic). Martin (1999) provides a useful summary of the most likely porewater pressure regimes in upstream-raised tailings impoundments, with examples of how dangerously unconservative assumptions of hydrostatic conditions for geotechnical analyses can arise from inappropriate piezometric monitoring.

Although every geotechnical instrument should be installed and monitored with a stated purpose and not specified ad hoc for the sake of increasing the tailings impoundment database, every opportunity should equally be made in locating sampling boreholes or taking advantage of piezocone sounding programs to also install piezometers with the intent of obtaining useful information for verifying design porewater pressure and seepage gradient conditions. Piezometer installations generally represent a small additional capital expenditure to a borehole or piezocone program, and the extra operational cost to acquire and process data is usually not significant, particularly with appropriate use of data loggers.

Regardless of the type of borehole piezometer used, complete installation details must be recorded in the instrument database. In addition to date, equipment, methodology, personnel and materials used, this information must include estimated or measured depths to in situ and backfill materials as well as the perforated pipe or transducer tip and the reference ground elevation. Too often long-term piezometer data cannot confidently be used to evaluate more recent in situ testing results because comparable elevations are not determinable or the length and location of the screened interval is not certain. Much of these uncertainties can be avoided by maintaining comprehensive but easily understood and useable data management and presentation (plotting) techniques: 
- The use of specialised software to maintain and chart (as opposed to acquire, for data logging systems) piezometer data should be avoided. Common worksheet programs are universally available and understood, and provide more than enough data storage and presentation capability for tailings impoundment piezometer applications.

- The primary y-axis should show elevation to easily incorporate changes to the piezometer installation (e.g. increased standpipe riser height) or adjacent ground conditions (e.g. tailings deposition or slope regrading).

- Recorded data should be converted to pressure head values and plotted with reference to the piezometer elevation head, as represented by one continuous, horizontal line (disregarding any longterm downward movement due to drag by tailings consolidation) for a transducer or two such lines for the top and bottom of the screened interval of a standpipe. The elevation of the base of the standpipe piezometer casing should also be plotted when the screened interval does not correspond to the end of casing. Alternatively, a schematic prepared to the same elevation scale as the chronological plot can be included alongside to illustrate adjacent in situ materials and the as-built piezometer. Inclusion of the piezometer tip or screened interval elevation allows for rapid identification of potential reading and data reduction errors such as trapped water between the bottom of the screened interval and the end of casing of a standpipe piezometer, a water surface below the bottom of a standpipe piezometer casing or an unreasonably large negative pressure head indicated by a vibrating wire piezometer.

- Elevations of the adjacent tailings surface, decant pond surface (if relatively close) and base of impoundment (or any other significant change of material or underlying boundary conditions, such as a co-disposed waste rock layer or seepage underdrain blanket) should be included to help assess boundary conditions on recorded pore water pressure data.

- Action trigger levels should be shown (referenced to elevations) if defined for the monitoring plan of the piezometer. Their positions (elevations) would be expected to change as the relevant geotechnical analyses are periodically updated over the operating life of the tailings impoundment.

- Where precipitation may influence pore water pressure response, a secondary y-axis or an adjacent plot to the same chronological scale showing daily rainfall (incremental or cumulative) is required.

- The in situ temperature (thermistor) data available from most vibrating wire piezometer transducers are often omitted from presentation or not even recorded. However, thermistor readings should be plotted at an appropriate scale with the piezometric head data, as temperature variations may indicate a change in seepage conditions associated with tailings deposition or other sources.

- Similar elevation and chronologic scales should be used for the presentation of data from piezometers located on common instrumentation lines or geotechnical sections.

The recommendations above are basic, but observations at numerous tailings facility operations indicate a wide standard of care in the collection, reduction, presentation and evaluation of piezometer data. Uncertainties in piezometer tip or screened interval elevations that reduce confidence in the estimate of porewater pressure regimes for deterministic slope stability analyses, for example, can to some degree be compensated by conservative assumptions of existing conditions (or alternatively, estimating appropriate probability density functions for probabilistic analyses). Alternatively, new or replacement piezometers can be constructed, subject to cost and schedule (installation and analysis) considerations. Nevertheless, perhaps a more significant concern is the compromised quality of long-term porewater pressure information that would otherwise have been more valuable, for example, for optimising piezocone sounding locations, validating dissipation test results, verifying tailings consolidation rates and assessing seepage underdrain performance.

\subsection{Seepage monitoring}

Monitoring of tailings impoundment seepage losses is fundamental to demonstrating environmental compliance, verifying seepage flux models (and by extension, design estimates of hydrogeological parameters) and calibrating water balance models. Deviations from predicted fluxes could indicate the need 
to revise assumed material parameters and conditions, such as permeability values and seepage gradients, or be symptomatic of operational problems, such as clogged collection pipes or direct connection with the decant pond in the case of an installed underdrain seepage collection system. In the worst case, localised seepage increases could relate to internal erosion and result in compromised structural stability and environmental contamination.

While adequate seepage monitoring is obligatory for the responsible management of all hydraulicallydeposited tailings impoundments, particular consideration is given here to the tracking of seepage from tailings storage facilities with interior underdrains. The requirements to diminish or prevent off-site seepage releases, improve water recovery during operation and reduce post-closure reclamation times are increasingly driving current designs to fully-lined impoundments with underdrain seepage collection systems installed over geosynthetic liners and/or low-permeability soil barriers, even in arid regions where high evaporative drying conditions lead to considerable settling and rapid consolidation under typical tailings particle size distributions and discharge rates. As summarised by Martin et al. (2002), the benefits of incorporating underdrain seepage collection layers above liner systems include the reduction of pressure head and leakage (through defects) across the liner and improved tailings consolidation and corresponding strength increase.

Constructed underdrain seepage collection systems have ranged from full sand or gravel blankets (most often with incorporated perforated drain pipes), to radial and herringbone arrangements of geocomposite strip drains attached directly to geomembrane liners, to gravel-lined trenches along upstream toes of perimeter embankments. Seepage water is removed via pump-off systems located above the liner or gravity systems which necessarily run through the liner and embankment, with selection based in part on liner integrity, cost and post-closure care considerations.

There does not appear to be a great deal of published information comparing modelled or estimated seepage rates to recorded values for a variety of underdrain seepage collection and removal system designs, with consideration of (or normalisation to) controlling factors such as hydraulic gradient, tailings permeability values and associated consolidation characteristics. Given the significant cost of constructing underdrain seepage systems, particularly for large impoundments incorporating full granular blankets, and the benefits of such systems to liner protection and tailings consolidation as noted above, every effort should be made to incorporate reliable and easily-accessible flow monitoring capacity in the design and ensure that seepage flow data are recorded continually throughout operation. Verification of estimated underdrain seepage system effectiveness over time, as tailings consolidation progresses and seepage flow paths increase with tailings deposition overhead, is vital to assessing the value of incorporating such systems in lined impoundments, particularly for comparison to other consolidation management strategies such as wick drain installation or reliance strictly on evaporative drying in arid climates.

Design and performance issues for which the comparative review of data from continual, long-term seepage rate monitoring from numerous tailings storage facilities could help resolve include:

- Continued development of large-strain tailings consolidation modelling through calibration of estimated boundary fluxes with recorded seepage rates (and other tailings deposit monitoring and testing data).

- Improvement of water and materials balance modelling through verification of estimated seepage loss rates, including resolution of any significant, transitory inputs such as intense rainy season precipitation and runoff inflows.

- Evaluation of full versus partial (under decant pond area only) seepage underdrain system options.

- Comparative performance of perforated pipes and geocomposite strip drains under tailings loading and consolidation.

- Efficacy of drainage blanket and imbedded collection pipe materials, dimensions and spacing designs.

- Comparison of decant pond operating strategies, such as a fixed pond and decant tower versus moving a pond within the impoundment interior and using a decant barge, with respect to development of the design final tailings surface, consolidation rate and reduced reclamation time. 
- Review of tailings discharge strategies for optimisation (with consideration of mill water demand from the decant pond) of spigot and impoundment cell cycling to promote consolidation.

- Evaluation of alternative discharge strategies such as periodic subaqueous discharge of whole tailings stream (if permissible under requirements of perimetral beach development and mill water demand) to provide additional surcharge on slimes thus promoting consolidation and reducing hydraulic connection between the decant pond and seepage underdrain system.

- Assessment of closure cover options using performance-calibrated seepage models.

- Reliability of predicted versus observed seepage water quality, and collection of baseline geochemical data for the development of post-closure water treatment strategies and costing.

- Reliability of predicted versus observed seepage water quantity, and refined estimation of postclosure seepage rates and duration for development of tailings impoundment remediation plans and costing.

The establishment and maintenance of a continual seepage rate monitoring record throughout tailings impoundment operation and into post-closure will aid greatly in the prediction of long-term seepage management requirements and provide baseline data to help resolve indications of any potential compromise to the underdrain system, such as pipe collapse, blocking by mineral precipitates or biological fouling. As importantly, a comprehensive seepage-monitoring database will facilitate long-term assessment of the selected closure cover system and help verify that tailings consolidation and strength development are consistent with post-closure geotechnical design assumptions.

\section{Concluding comments}

Adequate monitoring and in situ testing of deposited tailings are essential for the verification of geotechnical design parameters and performance assessment of tailings storage facilities in which the impounded tailings govern structural stability; topographic surveys, piezocone soundings, piezometer readings and seepage measurements are four basic monitoring and in situ testing methodologies for such facilities. Relatively recent technological advances such as GPS-based ground survey equipment, high-precision airborne photogrammetry, portable piezocone equipment, low ground-pressure vehicles, vibrating wire piezometers, electronic flow meters and stand-alone data loggers are generally widely-available at reasonable cost, resulting in the potential for more frequent and voluminous collection of data. Coupled with these technological advances are developments in empirical and theoretical-based estimates of tailings behaviour, including the assessment of liquefaction potential and large-strain consolidation modelling, which with modern computer systems can incorporate calibration to large datasets of field measurements.

The increased availability (i.e. relative ease of acquisition at low cost) of impounded tailings characterisation data thus provides an opportunity to establish and maintain long-term, continual records to verify design assumptions and to develop tailings-specific geotechnical databases and correlations, particularly when supplemented with other less-frequently conducted in situ testing and laboratory testing results.

For instance, borehole shear vane testing twinned to a piezocone sounding program would help calibrate the empirical cone factor used to estimate undrained shear strength from tip resistance, allowing greater confidence in piezocone-based shear strength estimates for that particular program and potentially for comparable piezocone work in other similar tailings deposits (with consideration of tailing characteristics, cementation and deposit stress history). Jefferies and Been (2006) stress the importance of measuring horizontal stress conditions for evaluating soil state and thus liquefaction potential; comprehensive stress measurement data would also be valuable for developing and/or calibrating tailings deposit consolidation and deformation models. Although in situ horizontal stress measurements are not often conducted in impounded tailings, such work would help refine site-specific assessments such as liquefaction potential and develop a better understanding of in situ stress distributions in similar deposits. Examples of valuable long-term monitoring data to verify design assumptions include the measurement of impoundment piezometric head distributions and seepage rates to assess underdrain seepage collection performance, or topographic survey and water accumulation records to help evaluate wick drain installation effectiveness. 
Collecting and transporting high-quality, undisturbed tailings samples for laboratory measurement of physical properties is difficult, given the fine-grained, non-cohesive characteristics typical of hard-rock mine tailings, the heterogeneous nature of most tailings deposits and the fact that most geotechnical parameters of interest are stress-dependent. Nonetheless, undisturbed tailings sampling is attempted (as is the preparation of representative specimens from reconstituted tailings samples), and the subsequent laboratory results can be used to develop correlations to in situ testing data, with consideration of estimated site conditions. Perhaps more usefully, such work can also help define reasonable variations that might be expected from in situ characterisation of similar tailings material under estimated impoundment conditions; an example of this would be the correlation of stress-normalised piezocone tip resistance to unit weight.

\section{References}

Blight, G.E. (2001) Evaporation from wet and "dry" beaches of tailings dams, in Proceedings 8th International Conference on Tailings and Mine Waste (Tailings and Mine Waste '01), Balkema, Rotterdam, The Netherlands, pp. 33-39.

Blight, G.E. (2003) Quantified comparisons of disposal of thickened and unthickened tailings, in Proceedings 10th Annual Tailings and Mine Waste Conference, Swets \& Zeitlinger, Lisse, The Netherlands, pp. 63-71.

Bussière, B. (2007) Colloquium 2004: Hydrogeotechnical properties of hard rock tailings from metal mines and emerging geoenvironmental disposal approaches, Canadian Geotechnical Journal, Vol. 44, pp. 1019-1052.

Davies, M.P., Lighthall, P.C., Rice, S. and Martin, T.E. (2002) Keynote Address: Design of tailings dams and impoundments, in Proceedings 2002 SME Annual Meeting, 25-27 February 2002, Phoenix, Arizona, USA, Society for Mining, Metallurgy, and Exploration, Inc., Littleton, Colorado.

Eldridge, T., Barrientos, M., Mussé, M. and Silva, M. (2007) Modeling tools for the development of tailings management plans, viewed 15 May 2010, http://www.infomine.com/publications.

Engels, J., Dixon-Hardy, D. and Birch, B. (2006) Thickened and paste tailings facilities-measuring the surface geometry, viewed 15 May 2010, http://www.infomine.com/publications.

Fourie, A.B. (2006) Above Ground Disposal, in Paste and Thickened Tailings - A Guide, 2nd edition, R.J. Jewell and A.B. Fourie (eds), Australian Centre for Geomechanics, Perth, Australia, 257 p.

Jefferies, M. and Been, K. (2006) Soil Liquefaction: A Critical State Approach, Taylor \& Francis, New York, 479 p.

le Roux, G.J.R. (2002) The effectiveness of single and multiple open standpipe piezometers in monitoring of the pore pressure regime in tailings dams, in Proceedings 9th Annual Tailings and Mine Waste Conference, Balkema, Lisse, The Netherlands, pp. 35-38.

Lunne, T., Robertson, P.K. and Powell, J.J.M. (1997) Cone Penetration Testing in Geotechnical Practice, Blackie Academic and Professional, $312 \mathrm{p}$.

Martin, T.E. (1999) Characterization of pore pressure conditions in upstream tailings dams, in Proceedings 6th Annual Tailings and Mine Waste Conference, Balkema, Rotterdam, The Netherlands, pp. 303-314.

Martin, T.E., Davies, M.P., Rice, S., Higgs, T. and Lighthall, P.C. (2002) Stewardship of tailings facilities, Mining, Minerals and Sustainable Development (MMSD) Working Paper No. 20, International Institute for Environment and Development (IIED).

McPhail, G. (2005) Getting the water balance right, viewed 15 May 2010, http://www.infomine.com/publications.

Morgenstern, N.R. and Martin, C.D. (2008) Landslides: seeing the ground, in Proceedings 10th International Symposium on Landslides and Engineered Slopes, Z. Chen, J-M. Zhang, K. Ho, F-Q. Wu and Z-K. Li (eds), Balkema, Christchurch, pp. 3-24.

Plewes, H.D., Davies, M.P. and Jefferies, M.G. (1992) CPT based screening procedure for evaluation liquefaction susceptibility, in Proceedings 45th Canadian Geotechnical Conference, Ontario, Canada, Vol. 4, pp. 1-9.

Qiu, Y. and Sego, D.C. (2001) Laboratory properties of mine tailings, Canadian Geotechnical Journal, Vol. 38, pp. 183-190.

Robertson, P.K. (2009) Interpretation of cone penetration tests - a unified approach, Canadian Geotechnical Journal, Vol. 46, pp. 1337-1355.

Schnaid, F. (2009) In Situ Testing in Geomechanics: The Main Tests, Taylor \& Francis, New York, 329 p.

Schneider, J.A., Randolph, M.F., Mayne, P.W. and Ramsey, N. (2008) Influence of partial consolidation during penetration on normalized soil classification by piezocone, in Proceedings 3rd International Conference on Site Characterization (ISC'3), A-B. Huang and P.W. Mayne (eds), Taylor \& Francis/Balkema, The Netherlands, pp. 1159-1165.

Seneviratne, N.H., Fahey, M., Newson, T.A. and Fujiyasu, Y. (1996) Numerical monitoring of consolidation and evaporation of slurried mine tailings, International Journal for Numerical and Analytical Methods in Geomechanics, Vol. 20, Issue 9, September 1996, pp. 647-671.

Shuttle, D.A. and Cunning, J. (2007) Liquefaction potential of silts from CPTu, Canadian Geotechnical Journal, Vol. 44, pp. 1-19. 
Stewart, D.P. and Randolph, M.F. (1994) T-bar penetration testing in soft clay, ASCE Journal of Geotechnical Engineering, Vol. 120, No. 12, December 1994, pp. 2230-2235.

Vick, S.J. (1990) Planning, Design and Analysis of Tailings Dams, BiTech Publishers Ltd., Vancouver, BC, 369 p.

Weemees, I., Howie, J.A., Woeller, D.J., Sharp, J.T., Cargill, E. and Greig, J. (2006) Improved techniques for the in situ determination of undrained shear strength in soft clays, in Proceedings 59th Canadian Geotechnical Conference, Vancouver, British Columbia, Canada, pp. 89-95. 